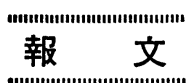

\title{
海底ケーブル外装用プラスチゾル塗装鉄線について
}

\author{
草 間 基* 鈴木 欽也** 小林 昌夫*** 鈴木 正義***
}

\section{On the Plastisol-Coated Steel Wire for the Armor of Submarine Cable}

\author{
Motoi Kusama, Kinya Suzuki, Masao Kobayashi \\ and Masayoshi Suzuki
}

For the armor-wire structure of submarine cable, a thin layer having good characteristics of anticorrosion and abrasion resistance is required as the surface layer of the armor wire. This paper describes on the plastisol-coated steel which is coated with uniform plastisol layer of about $0.3 \mathrm{~mm}$ thickness.

Adhesiveness between the plastisol layer and steel wire was measured, and the result showed strong resistance to peeling-off. Weatherometer test, outdoo ${ }_{r}$ exposure test and immersion test in sea water have been continued for several years, and no defect due to deterioration of the material was found out. It was considered that pinholes, if any, which may be occasionally formed in the manufacturing process would be sealed up by the so-called "electrocoating phenomenon." The result of investigation on the mechanical properties of this layer showed a good abrasion resistance in case of being pressed by small force such as exerted by fine sand.

It was concluded that submarine cable having this armor wire had good performances owing to its anti-corrosive characteristics in the circumstances of sea bottom for long terms, the mechanical strength being not affected by elongation and rotation of the cable, and also it had economical superiority.

\section{1. 緒言}

海底ケーブルは一般に数十年の寿命を要求されている が, 実状は 10 年末満で障害を起こすものが多い。障害 件数のうち外装鉄線の腐食によるものが約半数をしめて いる。

海底ケーブルの腐食の原因には, 主として海潮流起電 力による電食と, 海底の環境に基づく自然腐食がある。 これらの対策としては, 外部的な電気防食法もあるが, 鉄線自体を防食被覆することも有力な対策である。

海底ケーブルの外装鉄線の被覆の一例として防食効果 の大きいプラスチゾル塗装鉄線について，筆者らは数年 前より研究を重ねてきた。本報告は外装鉄線として要求 されるその物理的・化学的性能および実際の試験結果に ついて述べたものである。

\section{2. 海底ケーブル外装の技術的問題点とその経過}

海底ケーブルの鉄線外装はつぎの目的でほどこされ る。

（1）海底ケープルを布設したり引き揚げたりすると きにケーブルが切断しないように保護する。

* 日本電信電話公社電気通信研究亲 (東京都武蔵野市緑町 3-9-11)

** 国祭電信電話株式会社（東京都千代田区大手町 1-5)

*** 三信工業株式会社横浜工場（横浜市保土谷区星川町 3-500）
（2）波浪, 潮流, 海流等の海水の移動により,ヶー ブルが砂，石，岩石などとこすれて摩損したりあるいは 切断したりしないように保護する。

（3）投錨，漁撈等の人為的障害からケープルを守 る。

以上の目的を達成するために外装鉄線として要求され る技術的条件はつぎの通りである。

（1）布設，引き揚げの際にできるだけケーブルがの びたり，回転したりしないものであること。これはとく に中継器入り海底ケーブルの場合に問題となる。

（2）機械的摩損をできるだけ受けないこと。また， 電食によって鉄線が欠損し，外装鉄線が切断したり，引 張り強さが減少しないこと。すなわち，海底下で長年月 機械的強度が変化しないものであること。

(3) 漁具, とくに“スマリ”のようなするどい針を もった漁具に対しても内部のケーブルを保護できるこ 之。

(4) 経済的に安いこと。

従来覀鉛メッキ鉄線にコールタールを塗布したもので ケーブルを外装し，その上をジュートでおおう構造のも のが長く用いられてきたが，これは腐食，とくに潮流に 基つく起電力による電食に対して弱く, 鉄線が腐食, 切 
断してケープルの障害を起こす原因となっていた1)。 たこの点を改良するために PVC をチュービングし た防食型の構造のものが前記亜鉛メッキ鉄線にかわり用 いられるようになったが，これは鉄線と PVC 被覆の間 の接着力が弱いため, PVC 膜に損傷が与えられると海 水が水压により侵入し, PVC 膜と鉄線の間隙を横走り し, 防食力が弱まると考えられる。また, PVC 被覆は チュービングによるため, ある程度厚くなり鉄線相互間 の間隔が広くなる結果, “スマリ”などの漁具に対して も防禦力が弱い。一方, 太平洋横断ケープルの浅海部に 使用されたアメリカの外装鉄線はネオプレンを被覆した ものであるが, ネオプレン層が約 $1.3 \mathrm{~mm}$ となってい て厚いため, PVC 被覆と同様“スマリ”に対して弱い とともに鉄線径が小さくなった分だけ機械的特性を低下 せしめている。さらに材料費が高く, 加硫工程を必要と するので加工費も増える。本報告で述べるプラスチゾル 塗装鉄線は, これらの欠点を改良しようとして研究した もので, PVC ペーストレジンと熱硬化性樹脂を配合し たゾル状の物質を鉄線上に厚さ約 $0.3 \mathrm{~mm}$ の薄膜で均 一にやき付けて製造したもので，鉄線との密着性がすぐ れているという特徵を有し，また，機械的にも実用上差 支えない強度を持っており，長年にわたり安定した耐食 性を保有すると考えられる。以下にプラスチゾル塗装鉄 線の製造工程と主材料, 各種の試験結果, について述べ る。

\section{3. 製造工程と主材料}

PVC プラスチソ゚ルは PVC ペーストレジンに可塑剤, 安定剂, 増量剂を配合, 混練してペースト状とし, 常温 でダイス紋りで塗装できる状態としたもので, 海底ケー ブル外装鉄線の塗装には上記のほかに熱硬化性樹脂を添 加して, 焼成した塗膜の硬度を高くした組成を使用す る2)。プラスチゾルを $175^{\circ} \mathrm{C}$ 以上に加熱すればゲル化し 強䩖な塗膜となり, 押出法と比較して被覆のうすい均一 な被覆が得られる。

製造工程を図 1 亿示した。

\section{4. 試 験 結 果}

\section{1）耐食性}

プラスチゾル塗装鉄線の耐食性を試験するため, 鉄線 と皮膜の密着性の試験, ウェザオ試験, 屋外暴露試験な らびに海水浸漬試験, 塩水噴霧試験およびピンホール試 験を行なった。

\section{a）プラスチソル塗装鉄線の密着性}

鉄線と塗装皮膜の密着性注防食の見地からきわめて重 要である。写真 1 は米国ベル電話研究所における試験方 法を示したもので，試料の一部の皮膜を残して他部をあ らかじめはがしておき，鉄線の径よりわずかに大きい穴 のあいた器具を皮膜にかかるように通し, 引張試験機に

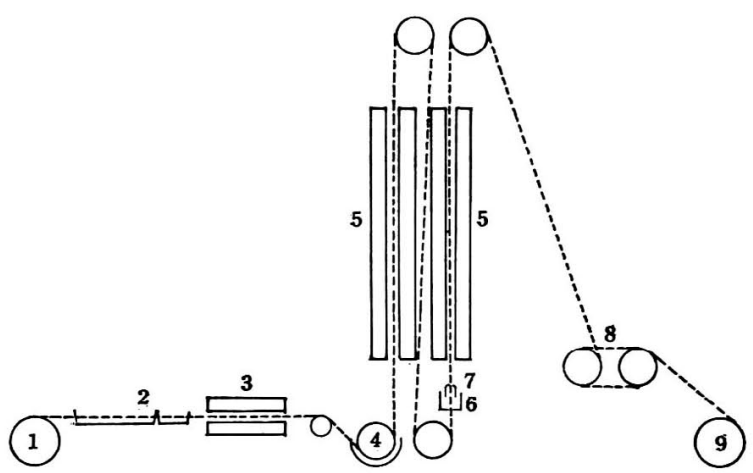
1: 送り出しドラム
2: 表面処理槽
3: 乾燥炬
4: 接着剤槽
5: 煰
6: プラスチソルタンク
7:フローティングダイ
8: キヤップスタン
9: 卷取りドタム

図 1 作業工程図

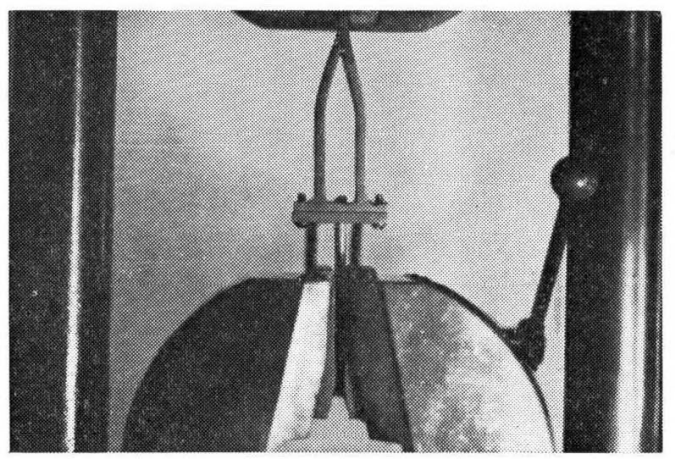

写真 1 密着性試験

表 1 各種被覆線の密着性

\begin{tabular}{c|c|rc}
\hline \hline 試 料 名 & 密着力 $(\mathrm{kg})$ & 備 & 考 \\
\hline プラスチソル涂装鉄線 & 123.6 & 膜厚 & $0.3 \mathrm{~mm}$ \\
ネオプレン被覆鉄線 & 42 & 膜厚 & $1.3 \mathrm{~mm}$ \\
PVCチチーービング鉄線 & 0 & 膜厚 & $0.5 \mathrm{~mm}$ \\
\hline
\end{tabular}

て引張り，皮膜をはがしたときの強度を求める方法であ る。表 1 はこの方法によるネオプレン被覆, プラスチソ゚ ル塗装および PVC チュービングの 3 種の密着性を比較 したもので, プラスチゾル塗装はネオプレン被覆の約 4 倍の密着性を有することが認められ，PVCチュービン グは全く密着性を示さない。

この密着性によりプラスチゾル塗装鉄線は完全水密構 造となり，耐食性を一段と強くしている。また，密着力 が強いため，プラスチゾルがその材料自体比較的伸びの 少ない硬い特性を有しているにもかかわらず，鉄線に焼 き付けられた状態では強勒な皮膜となり，捻回，引張り 強さ，低温脆化，加熱特性等の物理的な外力を加えた場 合に材料の特性以上の性能を示すことにより密着力がい かに重要であるかがわかる。 
b）プラスチソル塗装鉄線のウェザオ試験および屋 外暴露試験

ウェザオメーターの試験条件として紫外線の強さを標 準日射の 40 倍とし，150時間経過後の試験結果を表 2 に 示した。この結果, 試験前後において密着性, 耐摩耗性 〔試験方法については (2) a 項参照〕,引張り,強さ,伸び, 巻付, 捻回等の諸特性にほとえど変化が認められない。 これは製品に加工した後, 海底の比較的安定な環境に置 かれるまで，工場倉庫，布設船の船倉内など空気に接触 保管されてもその温湿度，紫外線等の環境变化によって 特性がかわらないことを示している。

また，別に行なった屋外暴露試験においても表 3 亿示 したように変化は認められない。

表 2 ウェザオメーター試験

試料: $6 \mathrm{~mm}$ 亜鉛メッキ銅線

\begin{tabular}{|c|c|c|c|}
\hline \multicolumn{2}{|c|}{ 試験項目 } & 試＼cjkstart験＼cjkstart前 & \multirow{2}{*}{$\begin{array}{r}150 \text { 時間後 } \\
134.4\end{array}$} \\
\hline 密 & 性 （kg） & 123.6 & \\
\hline 磨耗試験 & $\begin{array}{l}\text { 角 型 埾(荷重 } 1 \mathrm{~kg}) \\
0.8 \mathrm{~mm} \text { 鋼線（何重 } 2 \mathrm{~kg} ）\end{array}$ & $\begin{array}{l}110 \\
116\end{array}$ & $\begin{array}{l}105 \\
201\end{array}$ \\
\hline 筌膜の引 & 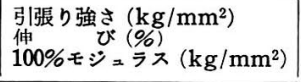 & $\begin{array}{r}1.94 \\
250 \\
1.02\end{array}$ & $\begin{array}{r}1.82 \\
220 \\
1.05\end{array}$ \\
\hline 巻付試験 & 丸棒巻付 & 陸膜に变化なし & 鈅膜に変化なし \\
\hline 捻回試験 & $\begin{array}{l}\text { 捻 回 数 } 5 \text { 回 } \\
\text { 捻 回 }\end{array}$ & 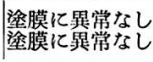 & \\
\hline
\end{tabular}

（注）プラスチソル筀膜厚さ $0.3 \mathrm{~mm}$

表 3 屋外暴露試験

試験開始：昭和 39 年 12 月 13 日

\begin{tabular}{|c|c|c|c|c|c|}
\hline \multirow{3}{*}{\multicolumn{2}{|c|}{ 試験項且 }} & \multicolumn{4}{|c|}{ 4mm 亜鉛メッキ鋼線 } \\
\hline & & 武験前 & 6 力月 & 1 年 & 1.5年 \\
\hline & & - & 昭40.6.14 & 昭40.12.18 & 昭41. 6.11 \\
\hline \multicolumn{2}{|c|}{ 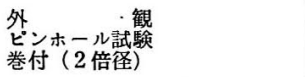 } & $\begin{array}{l}\text { 良 } \\
0 \\
\text { 良 }\end{array}$ & $\begin{array}{c}\text { 変化なし } \\
0 \\
\text { 良 }\end{array}$ & $\begin{array}{c}\text { 変化なし } \\
0 \\
\text { 良 }\end{array}$ & $\begin{array}{c}\text { 変化なし } \\
0 \\
\text { 良 }\end{array}$ \\
\hline 捻 回 & 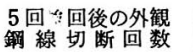 & $\begin{array}{l}\text { 良 } \\
13\end{array}$ & $\begin{array}{l}\text { 良 } \\
11\end{array}$ & $\begin{array}{l}\text { 良 } \\
10\end{array}$ & $\begin{array}{l}\text { 良 } \\
10\end{array}$ \\
\hline 摩耗試臨 & $\begin{array}{l}\text { ネマ式, 角型刃 } \\
\text { 荷重 } \\
1 \mathrm{~kg}\end{array}$ & 55 & 78 & 87 & 80 \\
\hline 引|㖘試験 & $\begin{array}{ll}\text { 荷 重 } & \mathrm{kg} \\
\text { 保 }\end{array}$ & $\begin{array}{r}1,295 \\
5.9\end{array}$ & $\begin{array}{r}1,350 \\
5.0\end{array}$ & $\begin{array}{r}1,325 \\
6.8\end{array}$ & $\begin{array}{r}1,275 \\
5.5\end{array}$ \\
\hline 着 & 性 & 良 & 良 & 良 & 良 \\
\hline
\end{tabular}

（注） プラスチゾル侳膜厚さ $0.3 \mathrm{~mm}$

\section{c）プラスチゾル塗装鉄線の海水浸漬試験}

外装鉄線は海底に長年月放置されるので，その経年変 化すなわち寿命は技術上最も重要な点である。鉄線, 亜 鉛メッキ鉄線またはタール塗装鉄線はこれが海水中にお かれたとき，数年を出でずして腐食することは過去の実 績の示すところである。さらに局部的な電食が付加され た場合その損耗は急激にすすむ。この意味で防食層の寿
命はすなわち外装線の寿命といいうる。実際の海底環境 においていかに安定であり，長年目にわたり変化しない かを示すためには実際にその年月使用するほかに明らか な証拠となりうるものはないが，初期の数年のデータか ら遠い将来を予想することは，ある程度可能である。プ ラスチゾル塗装鉄線が製造された当初, 昭和 38 年 3 月以 来試料を（写真 2 に示すように）横浜市中区新山下町横

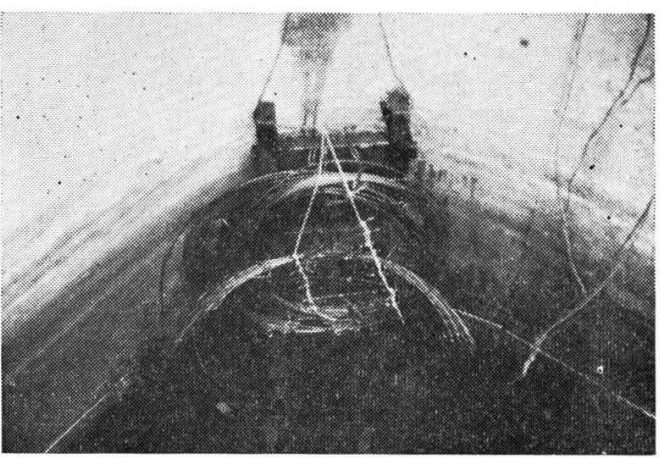

写真 2 海水浸漬状況

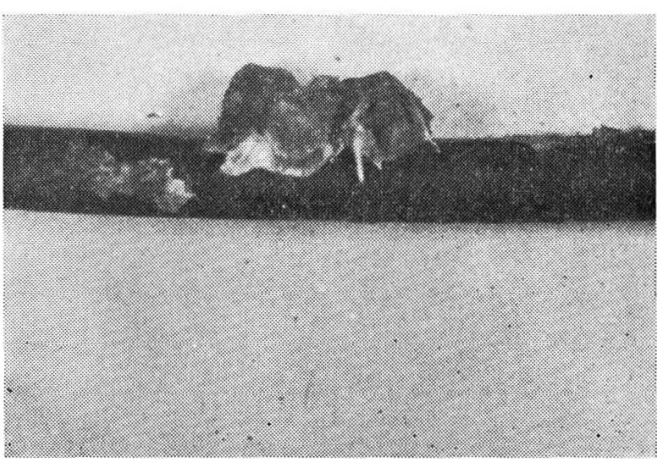

写真 3 海水浸漬試料 $6 \mathrm{~mm}$ 鉄線プラスチゾル塗 装面 2.5 年経過

表 4 海水浸漬試験

武験開始： $6 \mathrm{~mm}$ 画鉛メッキ鉄線 昭和 38 年 3 月 8 日 $4 \mathrm{~mm}$ 亜鉛メッキ銅線 昭和 39 年 12 月 27 日

\begin{tabular}{|c|c|c|c|c|c|c|c|c|}
\hline & \multicolumn{4}{|c|}{$4 \mathrm{~mm}$ 亚鉛メッキ鎆線 } & \multicolumn{2}{|c|}{ 6mm 鉄線 } \\
\hline & & & \multirow{2}{*}{ 間試験肖 } & \multirow{2}{*}{ 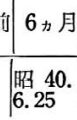 } & \multirow{2}{*}{ 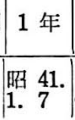 } & \multirow{2}{*}{ 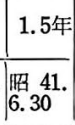 } & \multirow{2}{*}{$\frac{2 \text { 年 }}{\text { 昭40. } 4.10}$} & \multirow{2}{*}{$\frac{3 \text { 年 } 4 \text { 力月 }}{\mid \text { 昭 } 41.7 .}$} \\
\hline & & & & & & & & \\
\hline \multirow{2}{*}{\multicolumn{3}{|c|}{$\begin{array}{l}\text { 外 観 } \\
\text { ピンホール試驗 } \\
\text { 巻 付 ( } 2 \text { 倍径) }\end{array}$}} & 良 & 良 & 良 & 良 & \multirow{2}{*}{\begin{tabular}{|c} 
良 \\
(貝豰付着) \\
0 \\
良
\end{tabular}} & \multirow{2}{*}{ 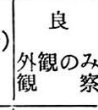 } \\
\hline & & & $\begin{array}{l}0 \\
\text { 良 }\end{array}$ & $\begin{array}{l}0 \\
\text { 良 }\end{array}$ & 良 & $\begin{array}{l}0 \\
\text { 良 }\end{array}$ & & \\
\hline 捻回 & 5 回 & $\begin{array}{l}\text { 捻回後の外擮 } \\
\text { 切 }\end{array}$ & $\begin{array}{l}\text { 良 } \\
10\end{array}$ & $\begin{array}{l}\text { 良 } \\
11\end{array}$ & $\begin{array}{l}\text { 良 } \\
12\end{array}$ & $\begin{array}{l}\text { 良 } \\
9\end{array}$ & 良 & \begin{tabular}{|l} 
浸漬続行 \\
至
\end{tabular} \\
\hline & 毁 & 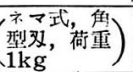 & 106 & 81 & 91 & 83 & - & \\
\hline 引張言 & 験 & $\begin{array}{ll}\text { 荷 重 } & \mathrm{kg} \\
\text { 伸 }\end{array}$ & $\begin{array}{r}1,790 \\
5.1\end{array}$ & $\begin{array}{r}1,770 \\
6.1\end{array} \mid$ & $\begin{array}{r}1,720 \\
7.6\end{array}$ & $\begin{array}{r}1,775 \\
5.5\end{array}$ & 二 & \\
\hline 密 & 着 & 性 & 良 & 良 & 良 & 良 & 良 & 良 \\
\hline
\end{tabular}

（注）プラスチソル叙膜厚さ $0.3 \mathrm{~mm}$ 
浜市設貯木場入口の水門わき海面に浸漬し長期海水浸漬 試験を続行中である。その後試料を追加しているが，当 初のもの性すでに 3 年半を経過している。写真 3 に示す ように皮膜に貝殼が付着しているが, 外観, 巻付, 捻 回, 引張り強さ, 密着性等の試験結果は表 4 に示すごと くいずれも劣化の傾向は見られない。

\section{d) プラスチソル塗装鉄線の塩水噴䙳試験}

試験試料を 60 日間, 食塩水濃度, $5 \%$, 温度 $35^{\circ} \mathrm{C}$ の 条件で噴霧し (JIS-Z-2371 の方法による), 外観を観察 したがなんら異常を認めなかった。また, 試験後 5 倍径 の巻付試験を行なったが皮膜にキレツあるいは割れなど の異常を生じなかった。

なお，別に塗装表面に縦に長さ $20 \mathrm{~mm}$ の傷をつけた 試料について 12 日間, $20 \%$ の食塩水を用い塩水噴霧を行 なったが，傷面の錆は進行せず，また皮膜のはがれはま ったく認められなかった。

\section{e）プラスチソル塗装鉄線のピンホール試験}

現在の製造工程では亜鉛メッキ鉄線に表面処理定施し た後，接着剂を塗布し，その上にプラスチゾルを焼き付 けている。しかし垔鉛メッキ鉄線の表面の仕上げが不完 全で微小の凹凸がある場合には，たまたま塗装工程でこ の凹みに小さな空気泡をいだいたまま塗料が表面をおお うことがある。このような場合には，つぎの焼付工程で 内部の気泡が膨張して表面の皮膜にピンホールをつくる ことが多い。したがってピンホールをなくすために亜鉛 メッキの表面仕上げを入念に行なうことが必要である。 現在この技術も向上しているのでピンホールの数も数百 $\mathrm{m}$ に 1 個という程度に減少させることができる。万一 ピンホールができた場合，防食に対しどのような影響が あるかについてつぎの実験を行なった。すなわち，海水 中に置ふれる鉄線はその周囲の海水に対して電位が十の 場合もあり，一の場合もある。たとえば潮流による起電 力においては流れの方向により鉄線の電位は海水に対し 十またはーとなる。この極性により電流がピンホールか ら流出したりあるいは流入したりすると考えられる。図 2 沙鉄線を一とし海水を+としてピンホール電流が時間 に対してどのように変化するかを求めたものであり，時 間の経過とともに急激に電流が減少していることがわか る。この説明はェレクトロ・コーティング3)としてすで に周知の現象である。すなわち, 海水中の主としてカル シウムイオン $\left(\mathrm{Ca}^{2+}\right)$ およびマグネシウムイオン $\left(\mathrm{Mg}^{2+}\right)$ が，鉄線のピンホール部分の電位がーのため, 集中的に ピンホール部に集められピンホールにこれらの塩が固着 し, 海水と鉄線との間の電気抵抗が大となり電流が流れ にくくなる現象である。プラスチゾル塗装ではピンホー ルの大きさは高々直径数十 $\mu$ という程度の小さなもので あるため小さな電位差でも容易に $\mathrm{Ca}, \mathrm{Mg}$ の塩ができ,

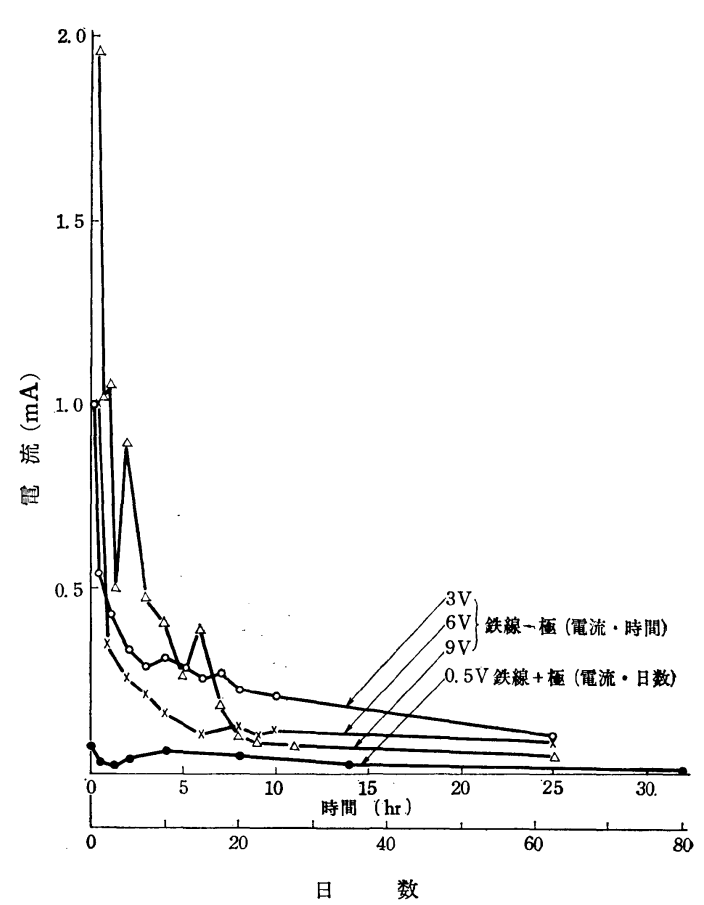

図 2 ピンホール電流の変化

試料：ピンホールは人口的に造ったものでその大きさは $0.2 \sim 0.3 \mathrm{~mm}$ である

これが緻密にかつ硬く鉄面に密着するため簡単には利離 しない。眓 2 に電位差を種々变えた場合の電流減少の状 態を示しているが，電位差の大きいほど $\mathrm{Ca}^{2+}, \mathrm{Mg}^{2+}$ イ オンが加速され早く塩の固形物ができることがわかる。 電流の流入部はこのような現象により遅かれ早かれコー ティングされてしまうので, 電流が流入できず海水から 流入する電流も微小となり，この意味では流出もないと いうことになる。一度エレクトロ・コーティングができ てしまえば, 電位が逆になっても, ピンホールを埋めた 塩の固形物は安定で硬く密着しているため, なんら変化 せず防食効果を発揮する。

つぎに鉄線が十, 海水がーであるような環境の場合は どうであろうか。前図 2 にこの場合のピンホール電流の 変化を示してあるが, やはり電流は漸減していることが わかる。これは海水の $\mathrm{pH} 7.5 \sim 8.44)$ への状況下で注海 水中の $\mathrm{OH}^{-}$イオンと $\mathrm{Zn}^{2+}$ イオンが反応して生成した 水酸化两鉛 $\mathrm{Zn}(\mathrm{OH})_{2}$ がピンホール部にコロイド状で付 着する。水酸化亜鉛はカルシウム塩ほど硬くはないが, やはり電気的に絶縁性を有するためピンホール部はふさ がれると考えられる。

以上のようにプラスチゾル塗装鉄線では密着性が良い ため，たとえピンホールができても自然にふさがれ防食 に対して悪影響を与えないことがわかった。しかし, 密 
着性が悪くビンホール実効面積が大きい場合に相当する 他の方法，たとえばチュービングによる場合には上記の 効果はあらわれにくい。

\section{2. 機械的性能}

\section{a) プラスチソル塗装鉄線の耐摩耗性}

海底ケーブル外装鉄線には種々の機械的摩耗力が働ら くと考えられるが，とくに海底にあるケーブルに働らく 摩耗には種々の想定が行なわれる。しかし, サンゴ礁ま たはこれに類する岩磐にケーブルがひっかかり，こすら れるような場合は，たと光鉄線，鋼線であっても切断さ れるので，プラスチゾル，ネオプレンあるいは PVC チ ニービングなどのような防食層を考えてもこれに耐えら れるとは考えられない。したがってこのような場合はル 一トを選定するとき避けるべきであって，防食層の技 術的条件としてはあげる必要はないであろう。そこで常 識的な海底環境で摩耗に強いということが必要となる。 この場合次の三つの状況が考光られる。

1）布設中の布設機械すなわちドラムエンジン，シー ブなどを通過するときに与えられる摩擦力, 圧潰力

2）陸揚付近の波浪による細い砂の移動を想定した場 合の摩耗

3）ケーブルが海底を引きずられた場合，または海水 の移動によりケーブルが振動した場合の海底との接触部 の摩耗

上記 1) の外力に対してはヘンリースコットの圧潰試 験が参考となる。その結果は表 $\mathbf{5}$ に示すごとくプラスチ ゾル塗装鉄線は圧潰に対してはきわめて強い。2) およ び 3) の摩耗に対してはネマ式摩耗試験機（試料上に往 復運動をするバーがあり，これに摩耗材をはさみ荷重を かける。摩耗により皮膜が破れ鉄面が露出し電気的に接 触するまでの回数を摩耗回数とする) と，かご型の摩耗 試験機（細砂を摩耗材とする）を用い試験を行なった。

表 5 圧潰試験

\begin{tabular}{|c|c|c|c|}
\hline 料 & 潰 & 備 & 考 \\
\hline $\begin{array}{l}\text { プラスチソル塗装鉄線 } \\
\text { ネオプレン被鉄線 }\end{array}$ & $\begin{array}{c}1,800 l \mathrm{~b} \\
420 l \mathrm{~b}\end{array}$ & $\begin{array}{l}\text { 試料台幅 } \\
\text { 漬速 }\end{array}$ & $58 \mathrm{~mm} / \mathrm{min}$ \\
\hline
\end{tabular}

図 3 はネマ式摩耗試験機によるプラスチゾル塗装鉄線 とネオプレン被覆鉄線の摩耗特性を示したもので， 2 種 の被覆を比較した場合摩耗材の線径が太いとき（小さな 圧力）はプラスチゾルが強く，反対に線径が細いとき （大きな圧力）ではネオプレンが強いことがわかる。す なわち，波浪などにより細砂が移動した場合を想定すれ ば摩耗圧力は小さいものと考えられ，一般にネオプレン はどのような摩耗に対しても強い抵抗力をもっているが 小さな摩耗力に対してはプラスチゾルがネオプレンょり すぐれていると考えられる。なお，図 3 に摩耗材として

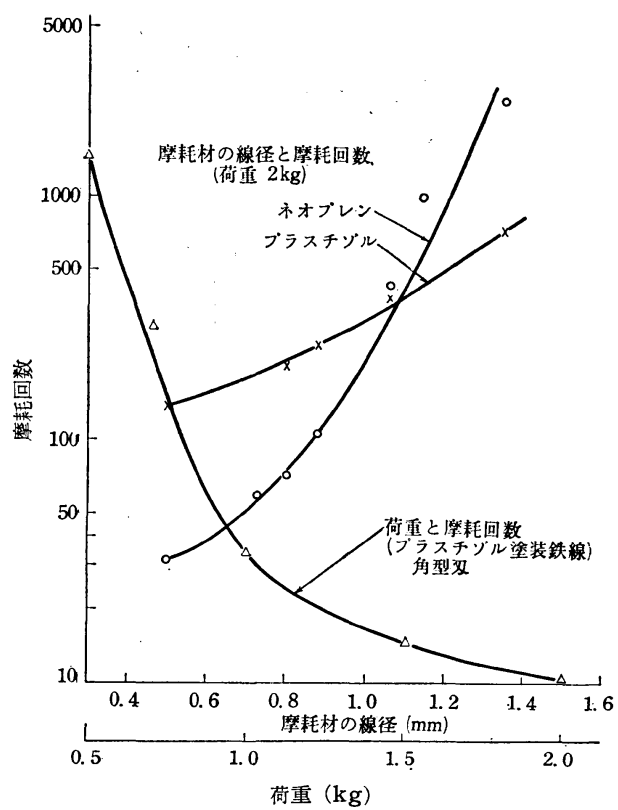

図 3 ネマ式試験機による摩耗試験

$90^{\circ}$ の角型刃を用いた場合の荷重と摩耗回数との関係を も示してあるが, 荷重の減少により摩耗回数が急激に増 加するプラスチゾル皮膜の特性がわかる。またかご型摩 耗試験機によってえられた結果も同様であり, 砂のあら さと関係し細い砂の時はプラスチゾルが良い結果をあた える。

つぎに 3) の外力は 2) の場合より一般に摩耗圧力は 大きいと考えられるが，海底を引きずる場合は布設また は修理の際に 1 回限りであり高々数百 $\mathrm{m}$ 止まりである ので普通の海底状態では問題はないと考えられる。しか し 3）の場合でケーブルが振動により局部的に摩耗を受 ける場合にはプラスチゾル塗装鉄線は皮膜厚さがうすい ことと，压力の大きな摩耗に対しては強くないことから 摩損を受けるものと考えられる。しかし，これによる摩 損は局部的に限られ，鉄線と防食層の密着性が泉いた め, この摩損を足場として腐食, 電食等の損耗が他部に 波及しにくいこと，またケーブルの全周にわたってこの ような摩損を受けることはないので，たとえ外装線のう ちの 1〜2 本が損耗を受け切断したとしても他の外装線 によって張力は十分保証でき，ケーブル障害にいたるこ とはないと考えている。

b） プラスチソル塗装鉄線の巻き付けおよび捻回試験 プラスチゾル塗装鉄線（素線径 $6 \mathrm{~mm}$ ) の巻き付け試 験では, 常温で $1 \frac{1}{2}{ }^{\prime \prime}$ 丸棒に 6 回巻き付けた場合, 巻 付後 $-25^{\circ} \mathrm{C}$ で 1 時間冷却した場合，また巻付後 $120^{\circ} \mathrm{C}$ の温度で 1 時間加熱した場合，いずれも外観になんら異 常は認められなかった。 
捻回試験では，つかみ間隔 $200 \mathrm{~mm}$ で $60 \mathrm{rpm}$ の速 度で捻回した場合，10回捻回しても異常がなく密着性が すぐれていることがわかる。この場合捻回後に故意に傷

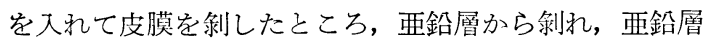
とプラスチゾルの密着力が僉鉛層と鉄よりもすぐれてい ることを示している。

\section{3. その他の試験}

\section{a) プラスチソル塗膜の吸水性}

鉄線より剩離した試料皮膜を室温で水中に浸漬し，1 カ月放置後の吸水率を求めた結果を表 6 に示した。表に は比較のためネオプレンについてももとめてあるが，ネ オプレンは吸水率がもっとも大きい。吸水状態における 引張り強さ, 伸び等の物理的特性は各材料とも吸水前と ほとえど変化がない。

表 6 各種皮膜の吸水率

試験条件：室温にて蒸留水中に浸漬

\begin{tabular}{|c|c|c|c|c|}
\hline \multirow{2}{*}{ 試 料 } & \multicolumn{2}{|c|}{ 吸水率\% } & \multirow{2}{*}{ 偖 } & \multirow{2}{*}{ 考 } \\
\hline & 7 日 & 1 力月 & & \\
\hline 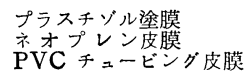 & $\begin{array}{l}0.29 \\
0.44 \\
0.20\end{array}$ & $\begin{array}{l}0.60 \\
1.34 \\
0.46\end{array}$ & 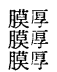 & $\begin{array}{l}0.3 \mathrm{~mm} \\
1.3 \mathrm{~mm} \\
0.5 \mathrm{~mm}\end{array}$ \\
\hline
\end{tabular}

\section{b）プラスチソルシートの物理試験}

厚さ $1 \mathrm{~mm}$ のシートを作成し試験した結果を表 7 に 記した。プラスチゾル塗装鉄線に使用するプラスチゾル は PVCレジンのほかに熱硬化性樹脂を含むため, PVC そのものの特性とは異なり, 熱を加えることにより㖇化 が進むため, 伸びの加熱後の残率が PVCより小さく出 る。

表 7 プラスチゾルシートの試験成績

\begin{tabular}{|c|c|c|}
\hline 試 験 項 目 & 試 験 結 果 & 備 \\
\hline $\begin{array}{l}\text { 张 り強 ざ } \\
\text { 华 } \\
100 \% \text { モーシュラス }\end{array}$ & $\begin{array}{c}2.47 \mathrm{~kg} / \mathrm{mm}^{2} \\
120 \% \\
2.38 \mathrm{~kg} / \mathrm{mm}^{2}\end{array}$ & \\
\hline $\begin{array}{l}\text { 加 熱 試 } \\
\text { 崄り験さ残率 } \\
\text { 伸び残 率 }\end{array}$ & $\begin{array}{r}114 \% \\
18 \%\end{array}$ & $100^{\circ} \mathrm{C}, 120$ 時間 \\
\hline 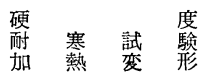 & $\begin{array}{l}60 \\
-5^{\circ} \mathrm{C} \\
28 \%\end{array}$ & $\begin{array}{l}\text { ショアー D型 } \\
100^{\circ} \mathrm{C}, 1 \mathrm{~kg} \text { 荷重 }\end{array}$ \\
\hline
\end{tabular}

\section{5）プラスチソル塗装鉄線を外装に用いた海底ケーブ ルの物理的特性}

\section{1）外装鉄線径の変動実績}

昭和 40 年末より約 6 力月間三信工業株式会社において 製造された $8 \mathrm{~mm}$ および $6 \mathrm{~mm}$ 鉄線の仕上り外径につ いて, 皮膜標準厚さ $0.3 \mathrm{~mm}$ に対し標準偏差は 0.017〜 $0.025 \mathrm{~mm}$ であり, また最小膜厚は $0.025 \mathrm{~mm}$ である。 2) プラスチソル塗装前後における引張り強さと伸び 塗装中の加熱により鉄線の引張り強さ, 伸びに変化が
ないかを調べるために塗装前後において鉄線の引張試験 を行なった結果, 塗装前後において引張り強さ, 伸びの 変化について有意差は認められず，材質的に変化がない ことを確認した。

\section{3. 海底ケーブルの伸びと回転}

図 4 および図 5 は海底ケーブルに張力を加えた場合, 張力と伸び, 張力と回転の関係を求めたもので, 内部の ケーブルの構造としては太平洋横断ケーブルに用いられ た SD ケーブルの場合である。 $\mathrm{L}_{3}, \mathrm{~L}_{4}, \mathrm{~L}_{5}$ 等の記号は外装 の種別を示すもので図 6 にその断面を示した。B は米国 ベル電話研究所のネオプレン被覆のものであり，A ラスチゾルを被覆した場合である。図によって明らかな ようにプラスチゾルの場合，鉄線径を太くできるのでケ ーブルの伸びあるいは回転は小さくなり，海底ケーブル としての特性は鉄線径の 2 乘に比例して向上する。また 水中重量, 比重が増大することにより, 海底に布設され た場合機械的に安定で波浪に動かされにくいことも長所 といえよう。また鉄線間隙がせまいため，スマリ等の漁

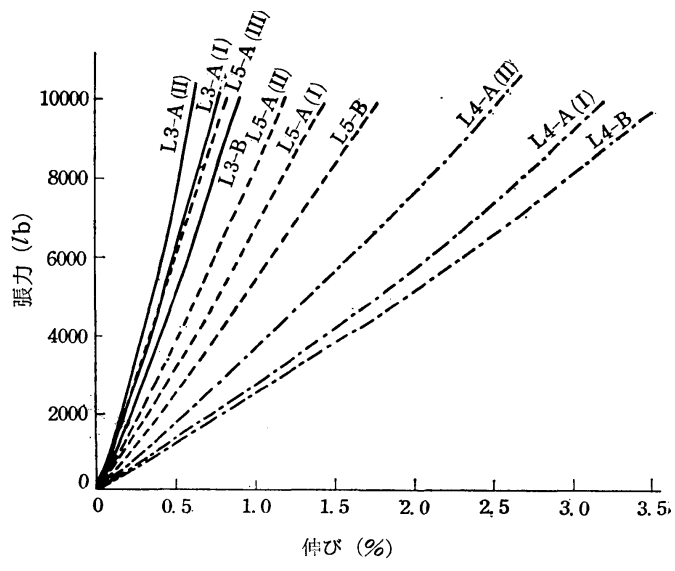

図 4 ケーブル張力と伸び

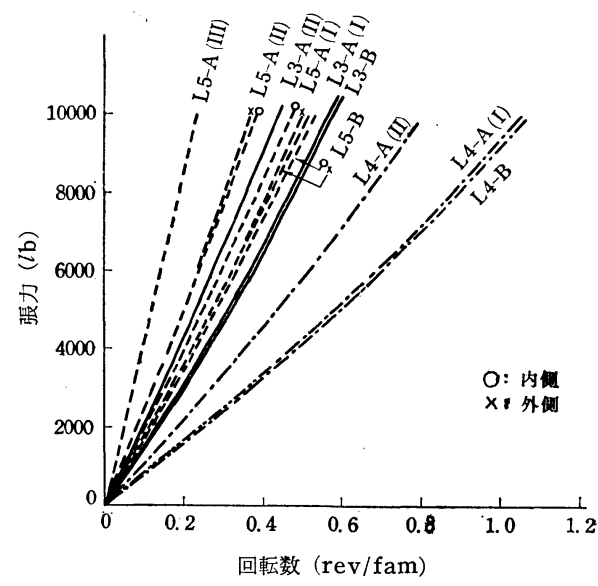

図 5 ケーブル張力と回転 


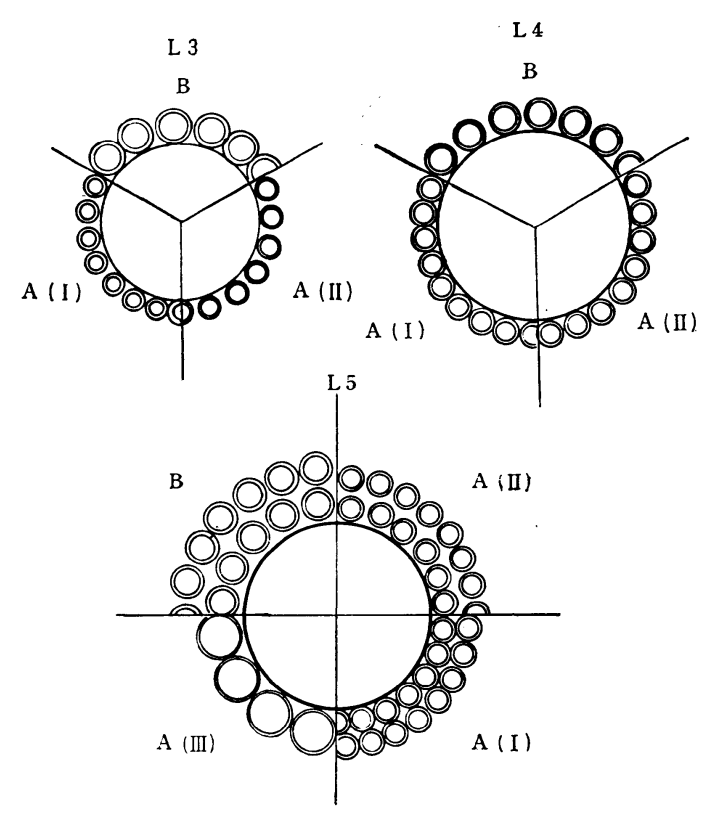

図 6 ケーブル外装断面図

具によってその針状フックが鉄線の間陌を刺し通すとい う障害に対しても保護できる。更に鉄線が太い点はいわ
ゆる“わらい”, スピユー, キンク等に対しても特性が 改善される方向である。

\section{6. 結 言}

海底ケーブル外装鉄線としてプラスチゾルを塗装し焼 き付ける方法について実験した結果種々の利点があるこ とがわかった。この方法により経済的にもネオプレンに よる方法よりも経済的で, 海底ケーブルの価格を低下せ しめることが可能となった。今後実施される太洋横断海 底ケーブルまたは国内海底ケーブルにこの新しく開発さ れた技術が役に立つものと思われる。

終りに本研究には古河電気工業株式会社横浜電線製造 所化学研究課の方々に種々のご援助をえた。厚く感謝の 意を表する。

(昭和 41 年 10 月 13 日受理)

\section{文献}

1）江副，鈴木：“海底ヶーブルの電食障害について”, 電気学会, 76, 609 (1956)

清野，江副，鈴木: “潮流下の海底ケーブルの電気障害に対する理 論的検討”, 電気学会, 77, 1079 (1957)

清野，江副，鈴木：“潮流下の海底ケーブルの電気障害に対する理 論的検討”(続), 電気学会, 78, 834 (1958)

2）特許公告，昭 39-5772

3）日本防錆技術協会編：“防錆技術便筧”，日刊工業新聞社（1958）

4) L.L. Shrein: "Corrosion of Metal and Alloys", Vol. 1 (1961)

\section{NACE Glossary of Corrosion Terms (3)}

Filiform Corrosion-Corrosion that develops under organic coatings on metals as fine hairlines, usually curved, wavy or coiled, and randomly distributed.

Fretting--Deterioration resulting from repetitive slip at the interface between two surfaces in a corrosive environment.

Galvanic Cell-A cell in which chemical change is the source of electric energy. It usually consists of two dissimilar conductors in contact with each other and with an electrolyte, or two similar conductors in contact with each other and with dissimilar electrolytes.

Galvanic Series-A list of metals and alloys arranged according to their relative potentials in a given environment.

Graphitic Corrosion-Corrosion of gray cast iron in which the metallic constituents are converted to corrosion products leaving the graphite intact.

Hydrogen Embrittlement-Embrittlement caused by entrance of hydrogen into the metal.
Hydrogen Overvoltage-Overvoltage associated with the liberation of hydrogen gas.

Impingement Attack-Localized erosion-corrosion resulting from turbulent or impinging flow of liquids.

Inhibitor-A substance which retards corrosion when added to an environment in small concentrations.

Interdendritic Corrosion-Corrosive attack which progresses preferentially along interdendritic paths.

Intergranular Corrosion-Corrosion which occurs preferentially at grain boundaries.

Internal Oxidation-See Subsurface Corrosion.

Ion-An electrically charged atom or group of atoms.

Local Action-Corrosion caused by local cells on a metal surface.

Local Cell-A galvanic cell resulting from inhomogeneities between areas on a metal surface in an electrolyte. The inhomogeneities may be of physical or chemical nature in either the metal or its environment.

Mater. Prot., 4, No. 1, 79 80 (1965) Jan. 